Michael Drolet

Worcester College, Oxford, OX1 2HB

michael.drolet@history.ox.ac.uk

\title{
Nature, Science and the Environment in Nineteenth-Century French Political Economy: the case of Michel Chevalier (1805-1879)
}

This article explores the significant yet neglected aspect of environmental awareness in nineteenth-century French political economy, and the French school of "industrialism", in particular. It focuses on the work of the one-time Saint-Simonian and political economist Michel Chevalier (1806-1879) as an interesting example of an environmentally sensitive political economy of "industrialism". The article reveals how Chevalier's political economy was informed by a sophisticated and environmentally conscious understanding of nature that came to mark scientific and engineering thinking in early nineteenth-century French academic circles. It shows how this understanding of nature was transmitted through publications and lectures of scientists and engineers within leading French academic institutions such as the École polytechnique and the École des mines. The article shows that Chevalier's scientific and engineering education at these institutions shaped his understanding of nature and society as intimately interconnected and mutually impacting. The article then shows how his view of nature and society developed in a more decidedly romantic direction during his time as a Saint-Simonian. The romantic sensibility of this time was short-lived, but a keen environmental awareness dating back to Chevalier's student days remained a significant feature of his later reflections in political economy. It was this particular quality of Chevalier's political economy that set it apart both from the French liberal school of political economy with its very low environmental awareness and the more fully ecological political economy of the kind advanced by his fellow Saint-Simonians, Pierre Leroux and Jean Reynaud. Finally, the article shows what has not been widely appreciated: that an environmentally sensitive political economy, of which Chevalier's was a good example, was endorsed by a large body of nineteenth-century French scientific and administrative opinion.

Key words: Nature, environment, environmental degradation, deforestation, chemistry, geology, climate change, pollution, industrialism, political economy, network, technology, sustainability, liberalism, socialism, Saint-Simonianism, organisation, society. 
In February 1864 France’s leading political economist, Michel Chevalier

(1806-1879), pondered the question of how to develop industry in the "conquered territory” of Mexico. ${ }^{1}$ The country had been invaded by French troops in 1862, and Napoleon III sought to lend scientific and cultural legitimacy to the occupation by doing what his uncle had done in the 1798 invasion of Egypt. He created a Scientific Commission. ${ }^{2}$ The investigative remit of the Mexican Scientific Commission was extensive. Many of its members came from the Institut de France and the Conseil d'Etat and were well placed to meet the challenge before them. Chevalier had belonged to both. As France’s most prominent political economist and leading advocate of "industrialism” he was eminently well qualified to investigate how industry might develop there. He also knew the country well, having travelled widely throughout it in 1835, and maintained contacts with leading members of its scientific community thereafter. In the years following his Mexican travels he wrote many articles and books about it. ${ }^{3}$

\footnotetext{
${ }^{1}$ A[rchives] N[ationales] de F[rance], F/17/2909 Exploration scientifique du Mexique.

${ }^{2}$ Numa Broc, "Les grandes missions scientifique française aux XIXe siècle (Morée, Algérie, Mexique) et leurs travaux géographiques", Revue d'histoire des sciences et de leurs applications, 34, (1981), 319-358; Gary S. Dunbar, “'The Compass follows the Flag': The French Scientific Mission to Mexico, 1864-1867)", Annals of the Association of American Geographers, 78, 2 (1988), 229-40; Numa Broc, "Le Mexique vu par les savants français (1865-1867)", in Daniel Meyran (ed), Maximilien et le Mexique (1864-1867) (Perpignan: Presses Universitaires de Perpignan, 1992); Paul N. Edison, “Conquest Unrequited: French Expeditionary Science in Mexico, 1864-1867”, French Historical Studies, 26, 3 (2003), pp.463-4.

${ }^{3}$ Chevalier described his travels in letters from April 1835 to Charles Béranger, Fonds Enfantin, Bibliothèque de l'Arsenal. Cited in Jean Walch, Michel Chevalier économiste saint-simonien (Paris: Vrin, 1975), 41. Chevalier's descriptions of Mexico appeared in five essays under the title "Lettres sur le Mexique", which appeared in the Journal des débats between 20 July and 7 September 1837. His later writings on Mexico included: Des mines d'argent et d'or du nouveau-monde (Paris: au bureau de la Revue des Deux Mondes, 1846); Le Mexique - Extrait de l'Encyclopédie du XIXe siècle (Paris: De Maulde et Renou, 1851); L'Expédition du Mexique (Paris: E. Dantu, 1862); Le Mexique ancien et moderne, (Paris: Hachette, 1864).
} 
Chevalier’s brief was challenging, as Mexico’s prospects for industrial development were poor. There were many reasons for this, but one he stressed was the decimation of its natural environment, particularly its forests, by its Spanish conquerors. The result was catastrophic. The Spanish paid no heed to, in Chevalier's words, the "utility of forests in moderating the climate and maintaining the water courses necessary for irrigat(ing)” Mexico’s crops and powering its industry. ${ }^{4}$ They transformed a flourishing "Eden” into "a barren and desolate” wasteland. ${ }^{5}$ This had a significant economic and political cost. Deforestation caused a decline in agriculture by depriving the soil of rich humus, starving it of essential nutrients. It altered Mexico’s climate, making it prone to frequent droughts. The loss of nutrients and rainfall led to significant soil depletion and erosion. As Mexico’s stock of cultivatable land shrank and became more infertile, its population's diet became more impoverished. This led to a drop in productivity, a loss of competitiveness and markets. The fall of Mexico’s economic fortunes led to the country’s political unrest. $^{6}$

Mexico’s economic, social, and political woes stemmed from the destruction of its forests: it was therefore logical for Chevalier to begin his investigation by exploring "the extent to which the country could be reforested." ${ }^{7}$ In this he expressed what had been well known for some time in French scientific and administrative

\footnotetext{
${ }^{4}$ Michel Chevalier, Des mines d'argent et d'or du nouveau-monde (Paris: au bureau de la Revue des Deux Mondes, 1846), p.7.

${ }^{5}$ Michel Chevalier, Des mines d'argent et d'or du nouveau-monde, p.7.

${ }^{6}$ Michel Chevalier, Le Mexique - Extrait de l'Encyclopédie du XIXe siècle (Paris: de Maulde et Renou, 1851), p.34.

${ }^{7}$ ANF, F/17/2909 Exploration scientifique du Mexique.
} 
circles: that whole regions and countries could be regenerated through reforestation. ${ }^{8}$ Throughout the 1860s and later decades the French state acted on that knowledge by replanting extensively its domestic and colonial forests. ${ }^{9}$ Chevalier's recommendations on reforesting Mexico therefore pushed at an open door. Yet they were never acted on. France's occupation collapsed in 1867 and with it the work of the Scientific Commission and Chevalier's sylvicultural and industrial ambitions for Mexico.

\section{Introduction}

The story of Chevalier’s attempts to reforest Mexico has never been told. But this should come as no surprise. In his day, Chevalier was one of France's most eminent statesmen and leading intellectuals, yet today he is a relatively neglected figure. ${ }^{10}$ When historians have considered his writings and achievements, they have been almost exclusively concerned with his participation in the Romantic socialist movement of the Saint-Simonians or with his role in negotiating in 1860 the first major commercial treaty between France and Britain. ${ }^{11}$ The question of whether his

\footnotetext{
${ }^{8}$ This opinion was borne out by rigorous scientific studies by amongst others, François Arago and François-Antoine Rauch. Baptiste Fressoz, “Modernity’s Frail Climate: A Climate History of Environmental Reflexivity”, Critical Inquiry, 38, (2012), 585-6.

${ }^{9}$ Caroline Ford, “Nature, Culture and Conservation in France”, Past and Present, 183, (2004), 180. The French state embarked on similar policies in Algeria. Caroline Ford, "Reforestation, Landscape, Conservation and Anxieties of Empire in French Colonial Algeria”, American Historical Review, 113, (2008), 341-362.

10 The reasons for this are discussed by Michael Drolet, "Industry, Class and Society: A Historiographic Reinterpretation of Michel Chevalier”, The English Historical Review, 123, (2008), 1234-40.

${ }^{11}$ Only a small number of works examine Chevalier's thought. See Marcel Blanchard, "Le Journal de Michel Chevalier”, Revue Historique, 171, (1933), 115-142; Arthur Dunham, The Anglo-French Treaty of Commerce of 1860 and the Progress of the Industrial Revolution in France (Ann-Arbor: University of Michigan Press, 1930); Arthur Dunham, "Michel Chevalier et le Traité de 1860”, Revue Historique, 171, (1933), 44-74; J.-B. Duroselle, "Michel Chevalier Saint-Simonien”, Revue
} 
work, and his political economy in particular, was environmentally informed has never been asked. As a mining engineer by training, and an enthusiastic exponent of infrastructure development - of the construction of railways, roads, canals, telegraphs, transatlantic telegraph cables, and even a railway tunnel under the English Channel $^{12}$ - Chevalier’s writings appeared to assign little or no space to nature. So asking the question of whether his political economy was environmentally informed appeared pointless. This article will challenge that long-standing view, and in doing so it will take aim at a number of orthodoxies about Saint-Simonianism and nineteenth-century French political economy. The main one it will challenge is that nineteenth-century French political economy harboured and transmitted values about growth and development that at bottom adopted, in the words of Michael Löwy, an "optimistic, 'promethean' conception of the limitless development of the productive forces”. ${ }^{13}$

This article will show the extent to which such judgements need to be revised, and it will do so by showing how nineteenth-century French political economy was a divided discourse over environmental questions. Many of the advocates - including Chevalier - of a significant school of nineteenth-century French political economy

Historique, 215, (1956), 233-266; P.-M. Schuhl, “Michel Chevalier saint-simonien”, Revue Historique, 217, (1958); Jean Walch, "Michel Chevalier et la puissance productive du travail”, Économies et sociétés, 4, (1970); Walch, Michel Chevalier économiste saint-simonien; Fiorenza Taricone, Il Sansimoniano Michel Chevalier: Industrialismo e Liberalismo (Firenze: Centro Editoriale Toscano, 2006); Jeremy Jennings, "Democracy before Tocqueville: Michel Chevalier's America”, The Revue of Politics, 68, (2006); David Todd, “Transnational Projects of Empire in France, c.1815-1870”, Modern Intellectual History, 11, (2014). Available on CJO 2014 doi:10.1017/S147924431400047X.

${ }^{12}$ Chevalier wrote numerous books, pamphlets and articles on these questions. See, for example: Michel Chevalier, Le système de la Méditerranée (Paris: Le Globe, 1832); Des intérêts matériels en France: travaux publics, routes, canaux, chemins de fer (Paris: Charles Gosselin, 1837); L'isthme de Panama: examen historique et géographique des différentes directions suivant lesquelles on pourrait le percer et des moyens à y employer; suivi d'un aperçu sur l'isthme de Suez (Paris: Charles Gosselin, 1844); Tunnel sous-marin entre la France et l'Angleterre sous le Pas-de-Calais: description des travaux préliminaires, puits de sondage, carte de sondages, profil en long (Paris: n.p., 1874).

${ }^{13}$ Michael Löwy, "For a Critical Marxism”, Against the Current, 12, 5, (1997), 33-34, cited in John Bellamy Foster, Marx’s Ecology: Materialism and Nature (New York: Monthly Review Press, 2000), 135. 
known as "industrialism” were aware of the environmental consequences and environmental limits of the development of productive forces whilst other exponents of the same school saw nature as something to be conquered. ${ }^{14}$

These differences stemmed from radically different intellectual starting points of advocates of industrialism. One group was intellectually grounded in the natural sciences and saw humanity and nature as intimately connected and mutually impacting. This group included the chemist and founder of the Société d'encouragement pour l'industrie nationale Jean-Antoine Chaptal (1756-1832). It adhered to what we might call a scientific naturalism that meant it considered nature to be central to considerations in political economy. It was interested in understanding the complex relationship between humanity and nature in order to manage economic development without destroying the environment through the squandering of natural and human resources. The other group was intellectually rooted in law, journalism, and politics. Its members, including Jean-Baptiste Say and Charles Dunoyer, founder of the shortlived but influential le Censeur and le Censeur européene, subscribed to an unalloyed Enlightenment optimism about the human condition, and were interested in understanding and removing constraints to individual liberty. This group’s war against ancien régime privilege caused it to view nature under a shadow cast by aristocratic custom. Its adherents viewed with suspicion preoccupations about land and nature, seeing them through an ideological lens that caused such concerns to be interpreted as expressions of an aristocratic

\footnotetext{
14 The English language scholarship on industrialism is limited but growing. Some notable works include: Richard Whatmore, Republicanism and the French Revolution: An Intellectual History of Jean-Baptiste Say's Political Economy (Oxford: Oxford University Press, 2000); Roberto Romani, National Character and Public Spirit in Britain and France, 1750-1914 (Cambridge: Cambridge University Press, 2002), ch.3; Helena Rosenblatt, “Re-evaluating Benjamin Constant’s Liberalism: Industrialism, Saint-Simonianism and the Restoration Years”, History of European Ideas, 30, (2004), 23-37, and Drolet, "Industry, Class and Society”.
} 
pastoralism. ${ }^{15}$ Nature was therefore stereotyped and viewed as an obstacle to human progress.

The existing scholarship on Chevalier situates his work within the school of industrialism, but it is divided over where to place him within it. Scholars that lined up with the neo-liberalism of the 1980s and 90s embraced F.A. Hayek's critique of Enlightenment rationalism and the kind of scientific mindset that culminated in the writings of Condorcet and Saint-Simon. ${ }^{16}$ They ignored Chevalier’s scientific background and saw his break with Saint-Simonianism and defence of free trade as confirming that he followed in the same trajectory as Dunoyer and his allies Joseph Garnier and Frédéric Bastiat.

Scholars interested in romantic socialism and inspired by Jean Walch’s 1975 Michel Chevalier Économiste Saint-Simonien rejected that liberal labelling, and cast Chevalier in the altogether different mould of Saint-Simon: Chevalier needed to be seen as a champion of what the French call, les grands projets - large-scale engineering projects that display an optimistic faith in the limitless potential of science and engineering to overcome nature. ${ }^{17}$ Both views are inaccurate. This is not only because Chevalier's thought represented a fusion of free markets and state

\footnotetext{
${ }^{15}$ This pastoralism, a dominant feature of French cultural life throughout the nineteenth-century, was given voice in the works of conservatives such as P.-M.-S. Bigot de Morogues', Essai sur les moyens d'améliorer l'agriculture en France (Paris: Tourneux, 1822) and Alban de Villeneuve-Bargement's, Économie politique chrétienne, ou recherches sur la nature et les causes du paupérisme en France et en Europe, et sur les moynes de la soulager et le prévenir (Paris: Paulin, 1834). Caroline Ford, "Nature, Culture and Conservation in France", 191-8

${ }^{16}$ F. A. Hayek, The Counter-Revolution of Science (Glencoe, Il.: The Free Press, 1952).

${ }^{17}$ Pierre Musso, Saint-Simon, l'industrialisme contre l'État (Paris: L'Aude, 2010), 180; Antoine Picon, Les saint-simoniens: raison, imaginaire et utopie (Paris: Belin, 2002), 111.
} 
sponsored grands projets, ${ }^{18}$ but that very fusion emerged out of a scientifically sophisticated understanding of nature.

What I will show in this article is that Chevalier's political economy was far more sophisticated than has been appreciated hitherto, and that its complexity owed much to considerations on nature and the environment. I will show that the origins to what we might call his environmentally sensitive political economy lay in the scientific and technical education he received at the École polytechnique (1823-5) and the École des mines (1825-9). Those who taught in these institutions were at the forefront of a new way of doing science that stressed multidisciplinarity and international collaboration. These scientists viewed science and nature holistically, understanding the latter as a complex circulatory organisation whose vitality and coherency could be altered either positively or negatively by human activity. The observations and experiments of Chevalier's teachers at the École polytechnique, François Arago, Louis Gay-Lussac and their close friend and collaborator, Alexander von Humboldt, ${ }^{19}$ on an impressive range of environmental questions, were critical to consolidating this view of nature as a complex web of life. Chevalier's teachers at both schools disseminated this knowledge in their courses and thereby made students aware of how humanity altered the natural environment and how nature could in turn effect - and change - humanity. As we will see, this form of instruction shaped fundamentally Chevalier's thinking on economic, political, and social questions.

\footnotetext{
${ }^{18}$ André Thepot's more refined reading of Chevalier showed how he affected a synthesis between Saint-Simonianism and economic liberalism. Picon's and Christophe Prochasson's work reinforce Thépot's argument. C. Prochasson, Saint-Simon ou l'anti-Marx (Paris: Perrin, 2005), 281. The argument is developed further by Drolet, "Industry, Class and Society”, 1230.

${ }^{19}$ Arago described Gay-Lussac and Humboldt’s friendship as "vive et profonde”. François Arago, Oeuvres Complètes, III (Paris/Leibzig: Gides et Baudry/T.O. Weigel, 1855), 17.
} 
When Chevalier abandoned his career as a mining engineer and joined the Saint-Simonians in the summer of 1830, the place he ascribed to nature grew and took on a decidedly romantic and imaginative turn. During the three years he was part of the movement, he and its other members reflected on how humanity and nature might be brought into harmony. Humboldt's discoveries and the innovative work of France's leading scientists proved both inspirational and intoxicating to the Saint-Simonians. ${ }^{20}$ The new scientific approach these leading scientists championed rested on philosophical foundations of diverse sources. But it was the impact of a particular type of German Naturphilosophie - owing much to Goethe and Friedrich Schelling - which was of great importance, as Humboldt made clear at the time. ${ }^{21}$ When the Saint-Simonians looked at nature and humanity through the lens of Naturphilosophie they affected, what Goethe and Schelling aimed for: a reconciliation of "the subjective world of the Self and the objective world of nature.”22 This opened an extraordinary vista for the Saint-Simonians, and offered a new way to reflect on the political and social unrest that had afflicted France for so long. ${ }^{23}$ In their estimation, the longstanding empiricist belief that an unbridgeable gap

\footnotetext{
${ }^{20}$ Chevalier describes his fascination with Humboldt's work in a conversation with Prospère Enfantin on 9 October 1832. He described Humboldt as “un homme fort avancé.” In Le Livre Nouveau des Saint-Simoniens (Philippe Régnier, ed)(Tusson: Du Lérot, 1991), 184.

${ }^{21}$ Humboldt admitted this. In writing to Arago, he stated: “Une prudence que tu approveras (j'en suis sûr) ajoute à des motifs plus nobles. Ayan quelque facilité de manier ma langue je puis aussi espérer d'influer sur une jeunesse qui s'est jettée jadis dans les écarts de la philosophie de la Nature, parce qu'on ne lui a pas montré que sans s'éloinger des verités physiques, on peut encore parler à l'imagination et à l'esprit." Humboldt to Arago, 30 April 1827, Correspondance d'Alexandre de Humboldt avec François Arago (1809-1853) (E.T. Hamy, ed.)(Paris: E. Guilmoto, n.d.), 31. Both Goethe and Schelling were great admirers of Humboldt. T. J. Reed, Light in Germany: Scenes from an Unknown Enlightenment (Chicago: University of Chicago Press, 2015), 127.

${ }^{22}$ Andrea Wulf, The Invention of Nature: The Adventures of Alexander von Humboldt, The Lost Hero of Science (London: John Murray, 2015), 128.

23 Saint-Simonians such as Gustave d'Eichtal championed, in the words of Michel Espagne, a kind of “panthéisme schellingien appliqué à la pratique sociale”. Michel Espagne, “Gustave d’Eichtal et l’Allemagne: critique biblique ou géopolitique”, Études saint-simoniennes (Philippe Régnier, ed.)(Lyon: Presses Universitaires de Lyon, 2002), 117.
} 
existed between the subjective world of the Self and the objective world of nature was the expression of a profound alienation of humanity from nature. This expressed itself politically and socially as the alienation of the classes, sexes, and individuals from one another. The Saint-Simonians’ goal became to eradicate social and psychological division. Central to that task was the more fundamental work of establishing a harmony between humanity and nature. This might have recalled the kind of unalienated individual life and social relations depicted in Rousseau's writings, except for the fundamental difference that the Saint-Simonians embraced science as the solution to this disharmony, unlike Rousseau, who saw it as contributing to the problem. ${ }^{24}$ Science, for them, was the key to understanding exactly how nature and humanity worked. With the knowledge accumulated from it, not only would humanity achieve, in the words of the Saint-Simonians, "universal association”, it would be united with nature. The new understanding of nature therefore delineated the contours of what Chevalier and the other Saint-Simonians called "industrial science". These considerations underscored the powerful belief that nature was a web of life and humanity was part of it.

Once Chevalier broke with the Saint-Simonians in 1833 he retreated from some of their more imaginative ideas, but not others, nor did he abandon the basic understanding of nature and humanity as bound together. As we will see, the near totality of his oeuvre from 1833 onward expressed ideas about circulation and web of life through the principal concept of the network. ${ }^{25}$ For Chevalier the network

\footnotetext{
24 Jean-Jacques Rousseau, Discourse on the Sciences and Arts, in The Discourse and Other Early Political Writings (Victor Gourevitch, ed)(Cambridge: Cambridge University Press, 1997), 3-28.

${ }^{25}$ See M. Drolet, "From the Nation State to the Community of Europe: The Origins and Evolution of Michel Chevalier's Theory of Complex Networks, 1829-1879”, Europe de papier: projets européens au xix ${ }^{e}$ siècle (Sylvie Aprile, et al.)(Lille: Presses Universitaires du Septentrion, 2015), 159-72
} 
fulfilled circulatory functions and had the power to unify disparate elements. It was akin to a living organism - analogous with nature itself. Its preservation and vitality depended on a well-organised and free circulation-flow between its constitutive elements. It also depended on the undistorted growth of these elements. Chevalier's preoccupations with infrastructure development, the economic issue of free trade within and outside national boundaries, and environmental matters, such as the squandering of natural and human resources, including his concerns over food waste, water and soil pollution and deforestation, were critical to his understanding of the network, and ensured that his political economy never deviated in its fundamentals from an industrialism informed by a scientific naturalism. These concerns were evidence of an environmental awareness that was integral to the network itself. Despite this, Chevalier's political economy did not translate into a full-blown ecologism that characterised the writings of other polytechniciens and SaintSimonians, such as Jean Reynaud and Pierre Leroux, champions of the idea of the circulus. ${ }^{26}$ While he may not have fashioned an ecological political economy, he did offer a version of it that, in stressing circulation, generative capacity and vitality, was congruent with organic organisation. ${ }^{27}$ It is this unique feature that would define his political economy and version of industrialism.

\section{Divided over Nature: the Divided Political Economy of “Industrialism”}

From its inception the school of industrialism was divided over nature. The leading exponent of industrialism, the chemist and founder in 1801 of the Société

\footnotetext{
${ }^{26}$ Dana Simmons, "Waste Not, Want Not: Excrement and Economy in Nineteenth-Century France", Representations, 96 (2006), 75.

${ }^{27}$ Walch, Michel Chevalier économiste saint-simonien, 427.
} 
d'encouragement pour l'industrie nationale, J.-A. Chaptal, considered nature to be central to considerations of political economy. As the author of the widely influential De l'industrie française (1819), Chaptal believed that industry could not be separated from nature. ${ }^{28}$ Other leading exponents of industrialism included Charles Dupin (1784-1873), contributing editor to the important Journal du génie civil, and Joseph Dutens (1765-1848). In Dupin’s important 1827 Forces productives et commerciales de la France, he described industry as "the combined forces of Man, animals and nature.” When he listed the elements that made up the "forces of nature”, he highlighted water, wind, steam power, and other elements such as soil, and organic waste, which contributed to soil’s “productive power”. ${ }^{29}$ For Dupin, two critical questions of political economy were, first, how best might these forces be harnessed? And, second, how best might they be sustained? Other advocates of industrie, such as Claude-Lucien Bergery (1787-1863) highlighted the role of the natural sciences, particularly chemistry, in answering Dupin’s two key questions. ${ }^{30}$ In setting down these questions Dupin differentiated one form of industrialism from another. The second form was championed by J.-B. Say, Charles Dunoyer, and Charles Comte. These authors, rather than seeing humanity and nature as intimately connected, saw nature as an obstacle to human progress: nature needed to be conquered, as Dunoyer put it in the opening sentence of his famous 1825 L'industrie et la morale:

\footnotetext{
${ }^{28}$ Jean-Antoine Chaptal, De l'industrie française (Paris: Antoine-Augustin Renouard, 1819), 5; Chaptal, Chimie appliquée à l'agriculture, Tome I, (Paris: Madame Huzard, 1823), xlix.

${ }^{29}$ Charles Dupin, Forces productives et commerciales de la France, I, (Paris: Bachelier, 1827), 12, 18, 23, 78, \& esp. 115. Chaptal makes a similar point in L'industrie française (Paris: Antoine-Augustin Renouard, 1819), 143-9.

${ }^{30}$ Claude-Lucien Bergery, Économie industrielle, Tome I (Metz: Mme V. Thiel, 1829), 75-7.
} 
Nous ne sortons de l'état de faiblesse et de dépendance où la nature nous a mis que par nos conquêtes sur les choses et par nos victoires sur nous-mêmes; nous ne devons libres qu'en devenant industrieux et moraux. ${ }^{31}$

The differences between these competing doctrines of industrialism were important. Whereas Say, Dunoyer, and Comte’s industrialism was narrowly utilitarian - couched in the mechanistic reasoning of "felicific calculus"32 - and committed to unfettered markets and free trade, Chaptal, Dupin, and Dutens' version of it was not and viewed unfettered markets with some suspicion, seeing in unrestricted competition, the evil of speculation, and the squandering of nature's resources: a dangerous combination that led inevitably to economic crisis and the weakening of national economy. ${ }^{33}$ Chaptal, Dupin, and Dutens’ industrialism embodied a fundamental commitment to the efficient and sustainable use of the nation's resources. There was an obvious environmental imperative to this, but there was a political and geo-strategic one too: an imperative that emerged out of the experience of the revolutionary wars and the Continental blockade. ${ }^{34}$ This form of industrialism understood resources in terms of their wealth generative "capacity” and saw short-term profit maximisation and speculation as squandering that capacity. This was a species of political economy that was much closer to the eighteenthcentury physiocracy than the industrialism championed by Say or Dunoyer whose aim was to free individuals from the constraints of ancien régime privilege -

${ }^{31}$ Charles Dunoyer, L'industrie et la morale considérées dans leurs rapports avec la liberté (Paris: Sautelet, 1825), 1. Dunoyer rejected those analyses that stressed the importance of nature to culture, and dismissed contemptuously Montesquieu's account. Ibid.,159.

${ }^{32}$ Benjamin Constant showed how industrialism's logic of felicific calculus rested on a crude idea of social organisation. Benjamin Constant, “De M. Dunoyer et de quelques-uns des ses ouvrages”, De la liberté chez les modernes: écrits politiques (Marcel Gauchet, ed.)(Paris, 1980), 543-62.

${ }^{33}$ Charles Dupin, Forces productives, i; Jean-Antoine Chaptal, Chimie appliquée à l'agriculture, Tome I, (Paris: Madame Huzard, 1823), xxiv-v.

${ }^{34}$ Francis Démier, “Charles Dupin: un libéralisme sans doctrine?”, in Carole Christen et François Vatin, Charles Dupin (1784-1873): ingénieur, savant, économiste, pédagogue et parlementaire du Premier au Second Empire (Rennes: Presses Universitaires de Rennes, 2009), 168. 
privilege they saw as undermining liberty and free markets. Say and Dunoyer's industrialism was couched largely in political and moral terms, whereas its rival version advanced by Chaptal, Dupin and Dutens was grounded in the natural sciences and a scientific-naturalist world view, inseparable from developments in chemistry and soil science in particular. ${ }^{35}$ As co-editor of the influential Annales de Chimie, Chaptal was one of the main contributors to developments in soil science. Many of his findings appeared in his highly influential and practical work, Chimie appliquée à l'agriculture, which described agriculture in vitalist terms, and emphasised the circulation of animal and plant waste to the improvement of soil nutrients. ${ }^{36}$ In highlighting these elements it also stressed the bonds between man and nature, ${ }^{37}$ offering a version of political economy that stressed circulation and organic growth. ${ }^{38}$ But it also anticipated, along with many other works described in influential journals such as the Annales de l'industrie nationale et étrangère, the important idea of the circulus - an idea that would also be anticipated by Chaptal's later successor to the

\footnotetext{
${ }^{35}$ The importance of soil science to nineteenth-century ecologism has been well-documented. Most of the scholarship tends to locate advances in soil science to the 1840s and the work of the German chemist Justus von Liebig. John Bellamy Foster, Marx's Ecology: Materialism and Nature (New York: Monthly Review Press, 2000), 147-77; Paul Warde, "The Invention of Sustainability", Modern Intellectual History, 8, 1, (2011), 170. This article, in following Dana Simmons, highlights the work of early nineteenth-century French chemists in reinforcing aspects of eighteenth-century physiocracy. Simmons, "Waste Not, Want Not", 76.

${ }^{36}$ In its preface Chaptal declared "Les lois de la vitalité sont immuables comme toutes les lois naturelles, mais la différence d'organisation dans les corps vivans en varie et modifie l'action, de manière que les produits diffèrent dans chaque espèce et dans chacun de leurs organes cette variété de produits a de quoi nous surprendre". Chimie appliquée à l'agriculture, Tome I (Paris: Mme Huzard, 1823), xv-xvi. On Chaptal's positive evaluation of Gay-Lussac and Thénard's chemical analysis of the importance of animal and plant waste to improving soil nutrients, see Ibid., 119-21.

${ }^{37}$ Chimie appliquée à l'agriculture, Tome I, xix.

${ }^{38}$ Chaptal described infrastructure in organic terms, stressing circulation and growth. "Ces grands moyens de communication forment les artères du corps social et en vivifient tous les organes." Chimie appliquée à l'agriculture, Tome I, xxviii.
} 
Société d'encouragement pour l'industrie nationale, Jean-Baptiste Dumas, and which Pierre Leroux and Jean Reynaud sought to popularise in the 1840s. ${ }^{39}$

Dupin and Dutens viewed soil and nature in terms similar to Chaptal. ${ }^{40}$ They were trained engineers and thoroughly immersed in a scientific community that, through the discoveries of its leading chemists, biologists, physicists and geologists was rapidly coalescing around a conception of nature as a complex web. ${ }^{41}$ For Dupin and Dutens nature harboured a potentiality that when scientifically harnessed led to the material improvement of humanity and the advancement of civilisation itself. ${ }^{42}$ This was the material stuff of wealth. Chevalier shared that scientific and engineering outlook and was introduced to it through the education he received at the École polytechnique and the École des mines.

\section{Scientific Education and Nature as "Web of Life"}

\section{i. The École polytechnique}

By the time Chevalier entered the École polytechnique in 1823, the view of nature as a web of life had become common currency within the institution and its associated schools of application. During his two years at the École polytechnique, a

\footnotetext{
${ }^{39}$ Dana Simmons, "Waste Not, Want Not”, 75. In their joint Encyclopédie Nouvelle Leroux and Reynaud praise Dumas' work on organic waste. See their entry on manure, or engrais. Pierre Leroux \& Jean Reynaud, Encyclopédie Nouvelle, ou dictionnaire philosophique, scientifique, littéraire et industriel, offrant le tableau des connaissances au dix-neuvième siècle, par une société de savans et de litterateurs, Tome IV (Paris: Charles Gosselin, 1843), 802.

${ }^{40}$ Charles Dupin, Forces productives et commerciales de France (Paris: Bachelier, 1827), 130, 245. Joseph Dutens, Analyse raisonné des principes fondamentaux de l'économie politique (Paris: Courcier, 1804), 14.

${ }^{41}$ Dutens studied at the École royale des ponts et chaussées and Dupin graduated from the École polytechnique.

${ }^{42}$ Francis Démier, “Charles Dupin: un libéralisme sans doctrine?”, 167-8.
} 
large number of courses he was required to take reinforced this view. Chevalier followed the established curriculum, which was highly theoretical and involved courses in Analysis, comprising differential and integral calculus, mechanics, descriptive geometry, physics, theoretical and applied chemistry, geodesy, a course on machinery, industry and statistics. He was also required to take courses in architecture, topographical drawing, portraiture, landscape drawing, history and Belles Lettres, though there were significantly fewer lessons in these. ${ }^{43}$ Louis Cauchy and André Ampère taught him analysis and mechanics, and Felix Leroy taught him descriptive geometry and applied analysis. But it was the courses taught by GayLussac, chemistry and physics, and Arago, Geodesy, social arithmetic and machines - courses Chevalier excelled in ${ }^{44}$ - that introduced him to the theoretical foundations to the new approach to science that would shape his understanding of nature and humanity.

When Chevalier studied under Arago, the latter's adherence to a holistic view of science was firmly established. Arago counted himself as one of France's leading champions of the new approach to science that had begun with the work of Monge, Laplace, Lagrange, Levoisier and others. He was, along with Gay-Lussac, a member of the société d'Arcueil and the société philomathique. As with the societies' founders, Berthollet and Laplace, Arago and Gay-Lussac were ardent believers in their aims, which were to transform people's fundamental outlook on nature. In this they sought to displace an outdated scientific tendency toward over-specialisation and the separation of the different branches of science by stressing science's

\footnotetext{
${ }^{43}$ École Royale polytechnique, “Registre de l'instruction”, 1823-1824 \& 1824-1825, AEP X IIc 7.

${ }^{44}$ École Royale Polytechnique, “Registre des Notes”, 1823-1824 \& 1824-1825, AEP X IIc 8.
} 
multidisciplinarity ${ }^{45}$ - a goal that developed out of Berthollet’s belief that all natural phenomena were united by a single principle - collaborative international research, and making the latest scientific discoveries widely known and accessible to the wider public. ${ }^{46}$ On this latter point they advanced the work of the société philomathique through its journals: the Bulletin des Sciences and then from 1807 the Nouveau Bulletin des Sciences; both journals sought to popularise science and explore how theoretical advances could be translated into industrial applications, thereby, in Arago’s words, "serving as a sure guide to men of commerce, industrialists, the public and enlightened administration." 47

Arago and Gay-Lussac also aimed, like the members of both societies, to make science truly international by establishing close collaborative links with foreign counterparts. As we have already seen, they counted Humboldt as a close friend and collaborator. They also considered themselves allies in furthering the aims of his view of Naturphilosophie. ${ }^{48}$

Arago's inclusive vision of science was rooted in the philosophic and cosmopolitan outlook that stemmed from an important intellectual inspiration, Condorcet. Not only would Arago edit the whole of Condorcet's oeuvre, he drew on important elements of Condorcet’s social mathematics - particularly ideas about scientific method, statistics and probability - in teaching his course on social

\footnotetext{
${ }^{45}$ See the editorial introduction to Nouveau Bulletin des Sciences, Tome I, October, (Paris, n.p., 1807), iii-iv.

${ }^{46}$ Maurice Crosland, The Society of Arcueil. A View of French Science at the Time of Napoleon I (London: Heineman, 1967).

${ }^{47}$ François Arago, Oeuvres III, 50.

${ }^{48}$ Humboldt to Arago, 30 April 1827, Correspondance, 31. Arago, Gay-Lussac and Humboldt championed a more rigorously empiricist philosophie de la nature than other proponents of Naturphilosophie in Germany, such as Schiller. T. J. Reed, Light in Germany, 127.
} 
arithmetic and machines. ${ }^{49}$ Arago's lectures communicated a new template for methods of social investigation, and an important truth believed by Gay-Lussac and other leading French scientists, including Berthollet, Cuvier, Fourcroy, Thénard - and Humboldt himself - they shared with Condorcet: that the different disciplines were intimately interrelated, ${ }^{50}$ and that this interconnectedness expressed a deeper truth that all nature's phenomena were ultimately united. Arago’s lectures also aimed to convey another important objective derived from Condorcet and shared with the members of the société d'Arcueil and société philomathique, which was to bridge the gap between the natural sciences and the moral sciences. ${ }^{51}$ This had always been Condorcet's aim. But Arago went further, and allied himself more firmly with Humboldt and the aim of his conception of Naturphilosophie, when he stressed the close proximity of reason to imagination. ${ }^{52}$ He illustrated this point in his lectures by showing that since the middle of the eighteenth century there existed in France an important connection between engineers and artists $^{53}$ - an idea the Saint-Simonians would later develop in novel and interesting ways. This, he contended, injected a certain élan into French engineering, making it highly innovative. ${ }^{54}$ But it involved something more. This was that humanity expressed its vital connectedness with nature through the works it created. Theories about the beautiful and the sublime

\footnotetext{
${ }^{49}$ Pierre Crepel, "Le Cours d'arithmétique sociale de François Arago à l’Ecole polytechnique (1825): Transcription des notes prises par l'élève Hippolyte Renaud”, Bulletin de la Sabix, 4 (1989), 14-16.

50 The third of Arago’s lectures on probabilities and social arithmetic covered a wide-range of topics, especially ones pertaining to public health. In his treatment of mortality tables in his third lesson of 9 July 1825, he raised the issue of the "influence changes to climate had on the health of men”, "Cours de Professeur M. Arago Arithmétique Sociale - calcul des probabilités”, AEP IX Rocquemaurel.

${ }^{51}$ Barbara Haines, "The Inter-Relations Between Social, Biological, and Medical Thought, 17501850: Saint Simon and Comte”, The British Journal for the History of Science, 11, (1978), 21.

52 Humboldt to Arago, 30 April 1827, Correspondance, 31.

53 “2ième année, janvier 1825 - 4 $4^{\text {ième }}$ leçon, Cours des Machines”, AEP IX Rocquemaurel.

${ }^{54}$ Bruno Belhoste, La formation d'une technocratie, 105-9.
} 
presented the artist's connection with nature through feeling rather than calculation. And feeling enabled the artist, in the words of Elizabeth Powers, "to fuse all the parts of his subject into an organic whole.”55 One of the central messages of Arago’s lectures was that nature, art, science, technology, and society had to be understood in terms that acknowledged their union and the creative outpourings that came from it. ${ }^{56}$ This fundamental truth was also a feature of Gay-Lussac's research in chemistry, meteorology and agriculture, and it was conveyed in his courses in physics and organic chemistry. ${ }^{57}$ As the champion of a new way of doing chemistry, GayLussac, like his mentor Berthollet, stressed its multidisciplinarity. ${ }^{58}$ His lectures reinforced this by presenting an understanding of natural phenomena in complex relational terms. ${ }^{59}$ He did this by stressing the value of a strict experimental approach to chemistry. He broke from traditional teaching methods and embellished his lectures with experiments and concise diagrams in order to illustrate better the value of experimentation, and to stress the union of theory and practice. ${ }^{60}$ This was intimately bound up with promoting the value of the practical application of chemistry that, as a member of Chaptal's Société d'encouragement pour l'industrie nationale, he worked hard to find for industry and agricultural. ${ }^{61}$ His work would prove critical to the development of soil science, a field chemists such as

\footnotetext{
55 Elizabeth Powers, “The Sublime, ‘Über den Granit,’ and the Prehistory of Goethe’s Science”, Goethe Yearbook, 15, (2008), 41.

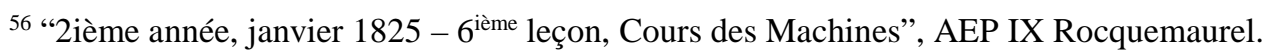

${ }^{57}$ Maurice Crossland, Gay-Lussac: Scientist as Bourgeois (Cambridge, 1978), 69 and 127.

${ }^{58}$ Crossland, Ibid., 43.

${ }^{59}$ Crossland, Ibid., 104.

${ }^{60}$ Sacha Tomic, "Le cadre matériel des cours de chimie dans l'enseignement supérieur à Paris au XIX siècle”, Histoire de l'éducation, 130 (2011), 65, 75.

${ }^{61}$ Arago noted the widely shared appreciation of Gay-Lussac’s influence on agriculture, and in particular the efficient use of manure. Arago, Oeuvres complètes, III, 108-9.
} 
Boussingault and Liebig would shape in their own distinctive ways, with both using developments in organic chemistry to tackle critical environmental questions such as soil depletion, the more efficient use organic fertilisers such as manure, deforestation and climate change.

Despite Arago’s and Gay-Lussac’s shared belief in the multidisciplinarity of science, of the need to conjoin it to the moral and political sciences, to popularise its latest developments, they could not agree on one of the major environmental questions of their day: how deforestation impacted on climate. ${ }^{62}$ Whereas Arago's studies concluded that it altered climate negatively, Gay-Lussac thought the question so complicated that he could not give a definitive answer to it. ${ }^{63}$ In his words: "these questions are so complicated that, when we examine them from a climatic point of view, the solution to them is very difficult, if not impossible to find.”64

In spite of the differing conclusions Chevalier's professors reached on one of the era's major environmental questions, they agreed on the multidisciplinarity of science and on how nature, society, science, and technology interacted in complex ways. This view was reinforced when, after graduating from the École polytechnique

\footnotetext{
62 The question was of such importance that the French ministry of Finance asked the Academy of Sciences to investigate it. Both Arago and Gay-Lussac were appointed to the commission along with Louis Costaz, Pierre Louis Dulong, Pierre Simon Girard, Charles-François Brisseau de Mirbel, and Augustin-François de Silvestre. Comptes rendus hebdomadaires des séances de l'Académie des sciences, III (Paris: Bachelier, 1836), 399. The commission's work dragged on for years due, in Arago's words, “to the large number of documents that it [was] necessary to collect” and study. Tableau Général des Comptes rendus hebdomadaires des séances de l'Académie des sciences (Paris: Mallet- Paris: Bachelier, 1853). Silvestre left the commission and Costaz and Girard died before its work could be completed. Boussingault, Dumas, and Duperrey replaced them. Comptes rendus hebdomadaires des séances de l'Académie des sciences, XIX (Paris: Bachelier, 1847), 403.

63 Their differing conclusions were discussed by Ludovic Beaussire, "Du défrichement des bois", Annales forestières, I, (Paris: Au Bureau de la Maison Rustique, 1842), 389. Though they differed on whether deforestation affected climate negatively, they agreed that there was a relation between forests and climate.
}

${ }^{64}$ Cited in A. C. Becquerrel, Des climats et de l'influence qu'exercent les sols boisés et non boisés (Paris: Firmin-Didot, 1853), vi. 
in 1825, Chevalier was admitted to his first choice of the ten possible schools of application: the celebrated École des mines.

\section{ii. The École des mines}

The course of study at the École des mines was directed toward the practicalities of mining. The curriculum included courses on geology, mineralogy, docimasy (the practice of ascertaining the quality and purity of minerals), mathematics, mine workings, draughtsmanship and descriptive geometry, and mining techniques and technology. The famous Brochant de Villiers and his leading disciples Armand Dufrénoy and Élie de Beaumont taught mineralogy and geology respectively. Pierre Berthier, the world's expert on blast furnaces along with Beaumont a member of the société philomathique, taught docimasy. Arsènne Baillet taught mine workings (exploitation des mines), André Guenyveau, author of the important 1810 Essai sur la science des machines, taught mineralogy, and Louis-Joseph Girard descriptive geometry and draughtsmanship.

The theoretical elements of the curriculum, such as the courses on geology, mineralogy and mathematics were critical to shaping students’ outlooks on geology, mining techniques, technologies, and nature. Brochant, Dufrénoy, and Beaumont’s courses on geology and mineralogy stressed a holistic understanding of the earth and a way of looking at the globe that reinforced what students had learned at the polytechnique. The lectures on geology and mineralogy stressed how geology, described as a "science of the earth", comprised “all the ways of envisaging” the 
globe. Brochant, Dufrénoy, and Beaumont stressed that they were teaching what the famous German geologist Gottlob Werner called geognosy. ${ }^{65}$

The impact of Werner's reflections on geology was significant. He counted Humboldt among his many famous students. In envisaging geology as a comprehensive science of the earth, Werner, along with other eighteenth-century German speaking investigators and Naturphilosophen, presented an understanding of nature as a dynamic interconnected entity. ${ }^{66}$ His revolutionary conceptualisation of the underground world as a complex network of veins and fissures ${ }^{67}$ was closely bound up with a belief stemming from Humboldt's professor Johann Blumenbach's Bildungstrieb that nature had to be comprehended in terms of vital forces. ${ }^{68}$ This understanding of nature resonated with the work of eighteenth-century physionomists, such as Xavier Bichat and Félix Vic d’Azyr, and would find echoes in Saint-Simon’s writings. It was a feature of what Paul Rabinow called a "biological-ecological model" of society. ${ }^{69}$ As we will see, it featured in Chevalier's mining reports - before he became a Saint-Simonian - and later works.

Where Werner's reflections on geognosy had the most significant impact in France was through Brochant’s work and that of his disciples Dufrénoy and Beaumont. Brochant's first course of lectures dating from 1810-11 drew on Werner's

\footnotetext{
${ }^{65}$ Brochant de Villiers, “Premier Leçon”, Cours de minéralogie et géologie, 1810-1811, 1. ENSMP Ms 39/214.

${ }^{66}$ M. Jackson, “Natural and Artificial Budgets: Accounting in Goethe’s Economy of Nature”, Science in Context, 7 (1994), 417.

67 This was elaborated by Werner in his 1791 New Theory of the Formation of Veins; with its Application to the Art of Working Mines.

68 Jackson, "Natural and Artificial Budgets”, 419.

${ }^{69}$ Paul Rabinow, French Modern: Norms and Forms of the Social Environment (Cambridge, MA: MIT press, 1989), 61.
} 
understanding of geology. ${ }^{70}$ The lectures he gave with Dufrénoy and Beaumont from 1825 emphasised that the science of geology was defined by a holistic view of the earth. One way of representing this, as the lectures made clear, was in the spatial representations of the situation and order of strata. Geology required knowledge of the organisational relation of strata forming the globe. This involved knowledge of the vertical and horizontal layering of strata, a topic of the second part of his lectures, which focused on the interior structure of the geological formations that made up the surface of the globe. ${ }^{71}$ Chevalier's writings as a mining student and candidate engineer replicated Brochant's characterisation of the interconnectedness of all strata, as did his Saint-Simonian reflections on urban planning.

Brochant, Dufrénoy, and Beaumont’s lectures on geology also included practical developments in field-research. When Chevalier entered the École des mines, the Dufrénoy and Beaumont were publishing the results of their six-month investigation of British mines and smelters in the Annales des Mines. Their seminal articles, published between 1824 and 1827, included accounts of the role infrastructure played in increasing the efficiency and profitability of mining, and discussions on environmental issues. ${ }^{72}$ An important article entitled Expériences qui ont été faites pour condenser les vapeurs qui se dégagent des usines à cuivre examined the air pollution caused by copper smelters of South Glamorgan, and the

\footnotetext{
${ }^{70}$ Philippe Grandchamp, "Le cours de géologie professé par Brochant de Villiers à l'École des mines dans les années 1810", Comité français d'histoire de la géologie (cofrhigeo) (séance du 14 décembre 2005) (Troisième série), 19, (2005).

${ }^{71}$ Brochant, Minéralogie et Géologie École pratique des mines de Paris, 1810-1811. ENSMP 10867.

${ }^{72}$ An example of that was their observation on mining in Staffordshire. Élie de Beaumont et Armand Dufrénoy, "Fabrication de la fonte et du fer en Angleterre”, Annales des Mines, I, ${ }^{\text {ième }}$ série, (1827), 373-4.
} 
various attempts to mitigate it by condensing fluorine, arsenic, and sulphur dioxide. ${ }^{73}$ Beaumont and Dufrénoy stressed the environmental costs of copper smelting. South Glamorgan was, in their words, "permanently enveloped by a whitish cloud which can be seen from a distance of many miles and whose corrosive effect destroys over several hundred toises the vegetation around it, and affects badly [plant life] from an even larger distance. These same gases are very offensive and are probably harmful to the animals that breathe them."74

These articles, published as Voyage métallurgique en Angleterre (1827), represented the seminal French study on Britain's geology and its mining industry - a fact acclaimed by Chevalier some years later ${ }^{75}$ - by locating them in a complex circulatory system, which comprised a comprehensive assemblage of both natural and human elements. The work, and the approach adopted in writing it - an approach that bore Brochant's imprimatur - had a major impact on how students, such as Chevalier, conducted their own field-research.

\section{iii. The place of Nature and the Environment in Chevalier's Mining Reports}

Field-research was a critical component of a student's time at the École des mines. Lectures and laboratory work, which took place in Paris and lasted from November until April, comprised a lot of field-study. ${ }^{76}$ But in the summer months' students devoted all their time to field-studies, or campagnes, as they were known. These involved visits to mines, smelters, and geological sites around France or

\footnotetext{
73 Élie de Beaumont et Armand Dufrénoy, "Expériences qui ont été faites pour condenser les vapeurs qui se dégagent des usines à cuivre”, Annales des Mines, XI, (1825), 242-54.

${ }^{74}$ Ibid, 243-4.

75 See Chevalier’s “Notice Nécrologique sur M. Coste, Ingénieur des Mines”, Annales des Mines, XX, (1841), 627.

${ }^{76}$ Louis Aguillon, L'École des Mines, 138.
} 
further afield in Belgium, the Netherlands, various Swiss cantons, German states or parts of Austro-Hungary. At the end of each campagne students wrote a number of reports. Between 1827 and 1828 Chevalier wrote four. ${ }^{77}$ He also wrote several more significant reports in 1829 as an aspiring (aspirant), then practicing, engineer. ${ }^{78}$ The reports resembled those of his contemporaries, which were inspired by Beaumont and Dufrénoy’s lectures and modelled on their work. They employed an investigative method that treated questions holistically in examining closely the interaction between people, natural resources, machines, industry, and the environment.

The template Chevalier employed was similar in all his reports. He began with a description of the local geography and geology, followed by a general account of the mine. He analysed how mines were integrated into the environment, the local and wider economy, and how they were connected to transportation infrastructure especially canals, navigable waterways, and railways. He examined the impact of mines and smelters on the local environment, paying particular attention to deforestation, water and air pollution, and their effects on agriculture. ${ }^{79}$ He also analysed the various industrial and domestic uses of different types of coked peat or coal. His investigations stressed the efficient use of resources and the economics of mining. These reports show that Chevalier was thinking about mines and industry in

\footnotetext{
${ }^{77}$ ENSMP Registre d'entrée des Journaux et Mémoires de Voyages des Élèves. Chevalier's unpublished reports were: (1) Mémoire sur l'Affinage du Fer dans la Vallée de Vicdessos (1827); (2) Mémoire sur le Gisement et l'exploitation du Fer Spathique dans la vallée de Baigorry (1827); (3) Mémoire sur la géologie des environs de Framont, sur le gisement et l'exploitation des minerais de fer qui s'y trouvent (1828); (4) Mémoire sur le gisement, l'exploitation, la préparation mécanique et le traitement du minérai de plomb dans le Münsterthal (1828).

${ }^{78}$ His published reports as an aspirant include: La carbonisation de la tourbe à Crouy-sur-Ourcq (1829); Notes sur la forge de Chavanon (1829); Observations sur les mines de Mons et sur les autres mines de charbon qui approvionnent Paris (1829); Rapports sur les mines de houille et de fer carbonaté que renferme la concession du Long-Terne, à Dour, royaume des Pays-Bas (1829).

${ }^{79}$ During his travels to Mexico Chevalier observed with horror the environmental and human cost of the "dry" method of silver amalgamation, which relied on mercury. Michel Chevalier, Des mines d'argent et d'or du nouveau-monde, p.47.
} 
terms of economies of scale, and their place within the interconnected networks of infrastructure, environment, natural and human resources, and consumption.

During his 1827 campagne Chevalier wrote about mines and foundries in the south of France. His journal de compagne, co-written with Pierre August Drouot and Louis Étienne Vène, ${ }^{80}$ gave detailed descriptions of the geography, geology, inhabitants, agriculture and industry, and tell us a great deal about workingconditions, technologies employed, and the environmental impact mines and foundries had on miners, agriculture, and forests.

The 1828 journal de compagne recorded problems of poverty and ignorance, highlighted well-organized uses of new industrial technologies and techniques, ${ }^{81}$ and stressed the importance of networks and efficient integration and circulation of natural resources to industry and markets. ${ }^{82}$ It also devoted much more time to the geology of the regions visited, especially strata and their vertical and horizontal interlayering: the kind of material that made up Brochant, Dufrénoy and Beaumont’s course on geognosy. In addition to his journal, Chevalier’s 1828 report Mémoire sur la géologie des environs de Framont built on those geological and technological considerations and made clear that nature's transforming powers could be reproduced by humans. ${ }^{83}$

\footnotetext{
${ }^{80}$ Chevalier wrote sections 2,3 , and 5 . Drouot wrote the first and fourth sections, and Vène wrote sections 6 through 9 .

${ }^{81}$ During Chevalier's 1828 campagne he accompanied two students in the year below him, Jean Reynaud (1806-1863) and Jean Martial Bineau (1805-1855). Journal de Voyage de MM Chevalier, Bineau et Reynaud, Année 1828, ENSMP Ms. J 1828 No.20. Like Drouot and Vène, Bineau and Reynaud became Saint-Simonians. Reynaud collaborated with Pierre Leroux in advancing a form of ecologism.

${ }^{82}$ Journal de Voyage de MM Chevalier, Bineau et Reynaud, Année 1828, ENSMP Ms. J 1828 No.20, part II.

${ }^{83}$ Chevalier, Mémoire sur la géologie des Environs de Framont, sur le Gisements et l'Exploitation des Minéraux de fer qui s’y trouvent. 27 December 1828, ENSMP Ms. M 1828 (73), 25-8.
} 
Whereas the 1828 report highlighted the transformative powers of nature, the two 1827 reports emphasised the destructive power of human ignorance. ${ }^{84}$ These reports tell us a great deal about Chevalier's knowledge and interests in mining, smelting, and environmental concerns, particularly the important problem of deforestation. Both reports showed how the wide-spread practice of clear-cutting, which took place in forests near mines and foundries, deprived these industries and nearby villages of a vital natural resource. The consequence was that wood had to be transported long distances on the backs of mules and men, a costly and timeconsuming proposition. Chevalier argued that the owners of mines in the valley of Baigorry had to be encouraged to undertake an ambitious programme of replanting, especially chestnut trees which he observed grew quickly, were an excellent source of charcoal as Pierre Berthier's chemical analyses had shown, and an important source of food. ${ }^{85}$ Several pages of this report are devoted to calculating the advantages of replanting and forestry management. Chevalier devoted an important section to showing the inter-relationship between mining, forestry management, and agriculture, reflecting on how much of the land near Baigorry was left uncultivated and barren, and that with the sustainable development of agriculture this would lower food costs and increase the size and productivity of the workforce through improved diet. ${ }^{86} \mathrm{He}$ concluded that the extensive replanting of decimated forests and their proper

\footnotetext{
${ }^{84}$ They were Mémoire sur le Gisement et l'exploitation du Fer Spathique dans la vallée de Baigorry (31 décembre 1827) and Mémoire sur l'Affinage du Fer dans la Vallée de Vicdessos (1827). ENSMP Ms. M 1827 (54) \& Ms. M 1827 (65).

${ }^{85}$ Chevalier, Mémoire sur le Gisement et l'exploitation du Fer Spathique dans la vallée de Baigorry, pt. I, 5-6. P. Berthier, “Analyse des cendres de diverses espèces de bois”, Annales de Chimie et de physique, 32 (Paris: Crochard, 1826), 248; Chaptal highlighted the important nutritional benefits derived from chestnuts. See his De l'industrie française, I, 244.

${ }^{86}$ Ibid., 5.
} 
management would assure the future of mining in the region. ${ }^{87}$ The same considerations were highlighted in his second report Mémoire sur l'Affinage du Fer dans la Vallée de Vicdessos, which recorded the widespread and damaging effects of deforestation on the local economy.

In commenting on all those deforested regions, Chevalier stressed the pressing need to re-establish once "great forests" before the "erosion” and the “depletion of the soil” made the task impossible. ${ }^{88}$ The issue was of critical importance to him, and became a central feature of his membership of the 1836 Société des Maîtres forges d'Ariège and his ambitious plans for a model forge, which involved the extensive reforestation of that region. ${ }^{89}$ It was a central consideration in the 1840s when Chevalier wrote extensively on gold and silver mining in Mexico, ${ }^{90}$ and, as we have already seen, in the 1860s, when he pressed for an ambitious plan to reforest Mexico. ${ }^{91}$

Mémoire sur l'Affinage du Fer dans la Vallée de Vicdessos also revealed another important environmental issue. This was the foundries' excessive water consumption and the impact this had on the local environment. In what was a clear use of Werner's Wasserwirtschaft (water economy), ${ }^{92}$ Chevalier showed how the region's foundries drew on considerable amounts of water in order to drive the

\footnotetext{
${ }^{87}$ Ibid., 9.

${ }^{88}$ Chevalier, Mémoire sur l'Affinage du Fer dans la Vallée de Vicdessos, $1^{\mathrm{er}}$ cahier, 14. See too $2^{\mathrm{ième}}$ cahier, 10-14.

${ }^{89}$ The Société's members, including Chevalier, were eager to see the reforestation of non-cultivatable land and hillsides. Jules François, Recherches sur le gisement et le traitement direct des minerais de fer dans les Pyrénées et particulièrement dans l'Ariège (Paris: Carilian-Goeury et Victor Dalmont, 1843), 392-3.

${ }^{90}$ Chevalier, Des mines d'argent et d'or du nouveau-monde (Paris, 1846), 7 \& 92.

${ }^{91}$ ANF F/17/2909.

${ }^{92}$ On Werner's Wasserwirtschaft see Jackson, “Natural and Artificial Budgets”, 411.
} 
steam-powered hammers that pounded the iron ore into a powder that could be smelted. This process was inefficient, slow, and wasted a lot of water, draining the reservoir that fed into it. This threatened the forests, upland pastures, and the local population's drinking water supply. ${ }^{93}$

Additional considerations in Chevalier's 1828 reports show the extent to which he thought of humanity and nature as mutually impacting. His Mémoire sur la géologie des Environs de Framont focused on the geology of the region, and made important observations on strata in areas of geological transition, especially the transforming power of nature, a power that could be harnessed through technology. ${ }^{94}$ He observed that areas of geological transition were extremely rich in valuable minerals, particularly where one stratum met another. Chevalier understood strata to be in movement, measured in geological time of millions of years. The meeting of moving strata yielded, according to him, tremendous energy with rich mineral wealth being the result. He highlighted this in an observation about scale and time, reflecting on geology and geological time in a way that uncovered certain fundamental properties about the physical universe, and by extension the human universe. ${ }^{95} \mathrm{He}$ established a connection between nature's creative energy, the ordering and synthesis of the globe, and human history. In articles he wrote for the Saint-Simonian journal Le Globe, and in later works, he transposed this idea of nature's ordering, synthesis and energy to civilisation. In short, he looked on human evolution in much the same way he looked upon geological change. In this he anticipated by a couple of decades Marx and Engels' materialist ontology and theory of history, both of which owed a

\footnotetext{
${ }^{93}$ Chevalier, Mémoire sur l'Affinage du Fer dans la Vallée de Vicdessos, $1^{\mathrm{er}}$ cahier, 11-14.

${ }^{94}$ Mémoire sur la géologie des Environs de Framont, sur le Gisements et l'Exploitation des Minéraux de fer qui s'y trouvent, ENSMP Ms. M 1828 (73), 28.

${ }^{95}$ Ibid, 25.
} 
great deal to Hegel's reading of Werner and the stress he placed on geological time and the phenomenon of spontaneous generation, or Generatio aequivoca. ${ }^{96}$

The meeting of the geological strata and the enormous mineral wealth it generated were mirrored in Chevalier's political and economic writings where he repeatedly contended that the union of different classes and peoples unleashed powerful productive forces that would create a more complex and higher form of synthetic unity ${ }^{97}$ This union, in turn, would catalyse those same forces, and they, in turn, would further consolidate the union. ${ }^{98}$ Geology and civilisation obeyed the same natural laws. They were evolving and complex organisations whose constitutive elements related to each other dynamically. The lesson Chevalier had learned as a mining student was that the destruction of nature and the squandering of natural and human resources led to a loss of vitality and collapse of complex natural and human systems. $^{99}$

The threat of that collapse grew considerably with the deteriorating political situation in France, which ultimately culminated in the July Revolution of 1830 . The events leading up to the Revolution and the event itself caused Chevalier to reassess his political convictions. The liberal values he upheld seemed unable to respond to

\footnotetext{
${ }^{96}$ On the relation between Marx and Engels' materialist ontology, theory of history, and Hegel's reading of Werner, see John Bellamy Foster, Marx's Ecology, 119-20.

${ }^{97}$ Chevalier made this point in his tenth letter on America reflecting on a new "race" of individuals he observed in the Western territories of the United States. The "man of the West" represented a fusion of the character of the "Yankee" and the "Virginian". As he noted: "Lorsqu'un troisième type, dont la supériorité est admise des deux autres, ou qui partage assez de la nature de l'un et de l'autre pour leur servir de lien et d'intermédiaire, vient se poser entre eux, il en resulte une vigoureuse organisation sociale; car alors l'harmonie entre les deux types primitifs a cessé d'être une abstraction; elle a pris chair et os." Lettres sur l'Amérique du Nord, I, 110.

${ }^{98}$ Chevalier, et al., Religion saint-simonienne. Politique industrielle et Système de la Méditerranée (Paris, 1832), 105.

${ }^{99}$ Chevalier's friend, fellow polytechnicien and mining engineer, Frédéric Le Play learned the same lesson. He addressed it in Des forêts considérées dans leurs rapports avec la constitution physique du globe et l'économie des sociétés (Fontenay-aux-Roses: ENS Fontenay-Saint-Cloud éditions, 1996), 151, 163, 180, 204.
} 
France's needs, and in particular to the needs of the destitute and vulnerable. Nor did they reflect fully the organic character of society - a character that was irreducible to a simple sum of parts. ${ }^{100}$ In August he yielded to the views and recruiting efforts of those of his cohort at the École polytechnique and École des mines who joined the romantic socialist movement, the Saint-Simonians.

\section{Saint-Simonianism, Nature and the Romantic Turn}

Chevalier's impact on the Saint-Simonian movement was immediate. Within a couple of months of joining he was writing articles for its journal L'Organisateur. By the end of the month, Prospère Enfantin the movement's leader, asked him to edit the Saint-Simonians' new acquisition, the famous liberal newspaper, Le Globe. Chevalier became its zealous editor-in-chief. Under his stewardship not only did the paper acquire the title "Journal de la doctrine de Saint-Simon", he wrote most of its articles.

Chevalier’s rapid rise coincided with a major schism between Enfantin and the movement's other leader Saint-Amand Bazard and Saint-Simon’s last disciple, Olinde Rodrigues. It also coincided with the defection of Jules Lechevalier and Abel Transon to Fourierism with its more thoroughgoing feminism and ecologism. ${ }^{101}$ While a detailed account of these developments would divert us from the topic of this article, two issues stand out as particularly relevant. First, the departure of Bazard and Rodrigues saw the Saint-Simonian movement enter a state of unbounded freethinking. Second, Lechevalier and Transon's readings of Fourier near the end of 1831 and

\footnotetext{
${ }^{100}$ Antoine Picon, “Générosité sociale et aspirations technocratiques. Les polytechniciens saintsimoniens”, Bruno Belhoste, Amy Dahan Dalmedico, Dominique Pestre, Antoine Picon (eds.), La France des X: deux siècles d'histoire (Paris: Economica, 1995), 148-9.

${ }^{101}$ On Fourier's ecologism, see Marie-Ange Cossette-Trudel, “La temporalité de l’utopie : entre création et réaction” Temporalités: Revue de sciences sociales et humaines, 12 (2010).
} 
beginning of 1832 - before their defection - posed a challenge to the movement's reflections on Saint-Simon. What was at stake was a central pillar to Fourierism and Saint-Simonianism, the idea of "universal association". The discussions that ensued from Lechevalier and Transon's readings of Fourier drove the Saint-Simonians to reflect anew on the theory and practice of association. And their unique scientific and engineering education, which stressed the interconnectedness of nature and humanity, furnished them with the intellectual resources that allowed them to imagine a world in which nature and technology were no longer in opposition but in union. These reflections, however, did not go far enough for the “dissidents”, and they finally broke with the movement in February.

In a pamphlet entitled Simple écrit d'Abel Transon aux saint-simoniens Transon challenged the Saint-Simonians conceptions of science and nature, arguing that they did not lead to their stated goal of universal association. Underlying this critique was the belief that Fourier was intuitively and scientifically right on nature. Fourier had shown in his 1822 Détérioration matérielle de la planète that "climatic disorders are a vice inherent to civilised culture”, because agricultural and industrial practices pitted humanity against nature. ${ }^{102}$ The objectification of nature led to indiscriminate land-clearance, deforestation, and climate change. ${ }^{103}$ Against this backdrop, Transon stressed the intimate union between nature and association, and argued that Fourier's thinking was firmly rooted in “incontrovertible” scientific principles that applied to “all theories of association”. ${ }^{104}$ This elicited a painstaking Saint-Simonian response, which involved an unrestrained reflection on nature and

\footnotetext{
${ }^{102}$ Charles Fourier, Détérioration matérielle de la Planète, in René Schérer, L'écosophie de Charles Fourier, (Paris: Anthropos, 2001), 67.

${ }^{103}$ Fourier, Détérioration, 75.

${ }^{104}$ Abel Transon, Simple écrit d'Abel Transon aux saint-simoniens (Paris: d’Everat, 1832), 20.
} 
visionary and decidedly more romantic ideas about technology. The role of the philosophy of nature (Naturphilosophie), and in particular, what Michel Espagne called a "Schellingan pantheism applied to social practices" became important to Saint-Simonian thinking. ${ }^{105}$ The natural properties of circulation and vital impulses were foregrounded in their reflections on universal association. These natural properties were seen as integral to both harmony and generative growth: to the realisation of nature's potentialities, which technologies would help unleash. These thoughts were among the Saint-Simonians' most imaginative on a theory of universal association, and ones that could easily meet the challenge of Fourier's reflections.

The Saint-Simonians explored many questions in this unbridled atmosphere. They reflected on time and space, and humanity's historical and spatial place in the world - important dimensions to a theory of universal association. ${ }^{106}$ Enfantin led discussions on topics that fascinated him, including cellular construction and circulation. Chevalier recorded many of these, and in a direct reference to circulation, he wrote that Enfantin thought: "MOVEMENT was the link between time and space." Underpinning this discussion was Enfantin's belief that modern science had given insufficient thought to questions of mechanics. The conversations that followed were numerous and touched on matters relating to engineering and architecture. They included one on the cycloid and cantenary arc, with Enfantin opining that the “complex idea cantenary-cycloid (...), embraced speed and mass, that is to say that VITAL FORCES must spring from it somewhere.”107 There were conversations on "universal dualism”, with Enfantin musing that "the day when we have assimilated

\footnotetext{
${ }^{105}$ Michel Espagne, “Gustave d’Eichtal et l’Allemagne”, 117.

${ }^{106}$ Richard Wittman, “Space, Networks, and the Saint-Simonians”, Grey Room, 40 (2010), 24-49.

${ }^{107}$ Conversation between Chevalier and Enfantin, 12 August 1832. Le Livre Nouveau, 174.
} 
sufficiently into our thoughts the new dogma, we will create the new mathematics founded on the universal dualism of those terms joined by a sympathetic element, alive, indefinite, comprised between two limits, oscillating and balanced between them.” ${ }^{108}$ And there were conversations on how vital forces and movement might be integrated into modern architecture and urban planning. In a revealing discussion of 7 September 1832 between Enfantin and his disciples, Chevalier reported that Le Père believed “architecture, as a theory of constructions, is an incomplete art” because "the notion of motion, of movement, is absent from it." While buildings were made to “RESIST MOVEMENT”, what was required was for “all buildings to be constructed in such a way as to receive MOVEMENT and to convey it." ${ }^{109}$ These thoughts were rooted in an understanding about circulation going back to biology, organic chemistry, and physiology. They coalesced around the idea that the modern city should adopt a natural form. The physical form of the human body was what Enfantin, like Saint-Simon before him, had in mind. ${ }^{110}$

The ideas to emerge from these conversations found their way into Le Globe and in poems. Chevalier wrote a number of poems, which employed bodily metaphors. La Terre, L'Eau, L'Air depicted the earth like the human body. Water was the blood which circulated through the body's arteries and veins, and air was that which "warmed and stimulated” it. ${ }^{111}$ His long poem Le Temple, which has been

\footnotetext{
${ }^{108}$ Ibid., 175.

${ }^{109}$ Chevalier and Enfantin, 7 September 1832, Ibid., 176.

${ }^{110}$ Ibid., 178-9. On the place of the body in Saint-Simon's thought, Frank Manuel, The New World of Henri Saint-Simon (Cambridge: Harvard University Press, 1956), 300-4, and Wittman, "Space, Networks, and the Saint-Simonians”, 34.

${ }^{111}$ Chevalier, “La Terre, L’Eau, L’Air”, Le Livre Nouveau, 245-6.
} 
described as "both surrealist and scientific", ${ }^{112}$ depicted humanity like the human body and saw its union with nature. The same poem also stressed new technologies that might harness the forces of nature, including lightning as a useable source of electricity $^{113}$ - an idea that was not entirely fantastical, given Chevalier's familiarity with Gay-Lussac’s research into electricity. This reflected the "new dogma”, of which Enfantin spoke and which was alluded to directly by Chevalier in another poem La Polarité Universelle. ${ }^{114}$ "Science marched toward universal polarity"; the “new science”, “new mathematics”, “new dogma” were all seen as intimately bound up with new technologies. These, in reflecting “new science”, were organic and not mechanical. Rather than being destructive of nature they would unlock nature's possibilities by promoting circulation and generative growth. The realisation of nature's potential translated into the realisation of humanity's potential, its “productive forces” and "generative capacity”, which expressed itself in economic, political, cultural and spiritual renewal.

The "voltaic battery temple" Chevalier described in Le Temple was to be the microcosmic expression of the life of the earth. His description of it was full of bodily metaphors. He stressed circulation and the temple's ability to use immense natural forces. It would harness the "light and heat" of the sun, and "electricity and magnetism” of the earth. It would emit fire and shoot out waves of heat and light. It housed "underground labyrinths and furnaces”. "Heat and electricity and pressurised steam (élastique vapeur)” would “circulate in its limbs”. ${ }^{115}$ It would bring together

\footnotetext{
112 Jean-Baptiste Duroselle, Itineraires: idées, hommes et nations d'Occident (XIX'-XXe siècles)(Paris: Publications de la Sorbonne, 1991), 139.

${ }^{113}$ Chevalier, “Le temple”, Le Livre Nouuveau, 237-43.

${ }^{114}$ Chevalier, “La Polarité Universelle”, Ibid., 251.

${ }^{115}$ Chevalier, “Le temple”, Le Livre Nouveau, 238.
} 
nature and humanity: "magnificent in the power of variety in its space”. It would contain all music, all the arts, paintings, sculptures, panoramas, dioramas, and much more. ${ }^{116}$ What Chevalier envisaged, as he made clear in a conversation with Enfantin, was a temple that brought together "in a single space all of space and all of time."117

The surrealism of these poems should not disguise the fact that the ideas they conveyed emerged out of knowledge of organic chemistry, physics, mathematics and geology that Chevalier and many of his Saint-Simonian confederates gained during their time at the École polytechnique and the École des mines. Their abiding preoccupation with circulation and movement and the more fundamental belief that only by uniting humanity and nature could social division be abolished, defined Chevalier and the Saint-Simonians' reveries, and their more sober reflections. ${ }^{118}$ They would define Chevalier's most important work as a Saint-Simonian: Le Système de la Meditérranée.

\section{Le Système de la Meditérranée}

In the winter and spring of 1832, and in the months before he wrote many of his surrealist poems, Chevalier organised a major and wide-ranging project for $L e$ Globe. This was 13 articles published between January and April under the heading Religion Saint-Simonienne: Politique industrielle et Système de la Méditerranée.

\footnotetext{
116 Ibid., 239.

${ }^{117}$ Conversation with Enfantin, 7 September 1832, Le Livre Nouveau, 181. Chevalier never abandoned the idea of bringing together all of humanity's achievements in a single space. He was president to the 1855 Paris Universal Exhibition, and president of the French delegation to the 1851 and 1864 London Universal Exhibitions. He also served on the 1867 and 1871 Universal Exhibitions' commissions.

${ }^{118}$ Conversation between Chevalier and Enfantin, 7 September 1832, in Le Livre Nouveau, 176.
} 
Chevalier wrote 9 of these. ${ }^{119}$ The ideas about cellular structure, circulation, vital forces, and new technologies were central to them. Many of the same ideas contained in his poems figured in altogether less fantastical forms in these articles. They would serve to underpin his vision of universal association, which comprised the economic, political, and cultural union of a divided Europe, and the integration of Europe and the Ottoman world.

Chevalier's fourth article set out in detail how that union would be achieved. He described a system - the Mediterranean system - that comprised a colossal infrastructure network of railways, navigable rivers, canals, roads, shipping lanes and telegraphs linking the port cities of the Mediterranean to each other and to the major capitals of Europe, the Middle East and Asia. Chevalier envisaged over 60,000km of railways linking Europe's and Asia's major cities. To these were added many tens-ofthousands of kilometres of canals, navigable rivers, and roads linking smaller towns and cities to major ones. And to these were adjoined scores of Mediterranean shipping lanes linking the major and minor ports of the Mediterranean basin. His scheme centred on the Mediterranean as the meeting point of East and West, and North and South - of the four poles of the globe.

The infrastructure network of the Mediterranean system was understood in terms of organic organisation. His description of it relied on bodily metaphors, the vocabulary of "veins and arteries" and "limbs". He argued that the strength and vigour of circulation determined the system's generative capacity. In his words the Mediterranean system was "a system of veins and arteries through which civilization

\footnotetext{
119 The four other articles were by Charles Duveyrier, Stéphane Flachat, and Henri Fournel. Though celebrated as among Chevalier's the most important published writings, editions of them remain fragmentary, and their scope not yet fully understood. For a more thorough appraisal of them see M. Drolet, “A Nineteenth-Century Mediterranean Union: Michel Chevalier’s Système de la Méditerranée”, Mediterranean Historical Review, 30, 2, (2015), 147-168.
} 
circulated awakening weary nations by bringing together disjointed limbs and causing them to move from a state of torpor to one of intoxicating activity.”" 120 The system’s generative capacity was not confined to nations and civilizations. It extended inward to communities, and down to the molecular level of the individual. Chevalier saw the national and the individual in a dialectical and symbiotic relationship. These ideas, like those expressed in Chevalier's earlier writings, were clearly informed by what he learned in Brochant, Beaumont, and Dufrénoy’s courses on geology and mineralogy, which, as we saw, stressed the situation, order, and organisational relation of the geological strata as being layered both vertically and horizontally, and the interaction of strata and unleashing of powerful geological forces, yielding rich mineral wealth. As if to replicate the multidisciplinarity stressed in the work of the societies of Arcueil and philomathique, these ideas were combined or paralleled with bio-physiological ideas about circularity, interaction, molecular structure, vitality and growth that Chevalier learned in organic chemistry and gleaned from his knowledge of Saint-Simon's reading of the eighteenth-century physiologists Bichat and Vicq d'Azyr. ${ }^{121}$ These ideas defined his thinking on the inner life of the individual and the outer life of society along with the more expansive categories of nations and peoples that he also used. The intricate system that connected the communal, provincial and national, he united to a wider geographic network. The resulting synergy, as in a dynamically evolving organism or the overlapping and merging of strata, transformed the nature and internal dynamics of the system, contributing to its growth and harmony. As Chevalier made clear in this

\footnotetext{
${ }^{120}$ Chevalier, Système de la Méditerranée, 136.

${ }^{121}$ For Saint-Simon's reflections on physiology see, for example, Mémoire sur la science de l'homme, in Oeuvres complètes, II (Paris: Gallimard, 2012), esp. 1103-22.
} 
work and numerous others, the Mediterranean system would evolve into a global system. $^{122}$

For all its flights of fancy, this visionary work established the fundamental and constitutive elements of the whole of Chevalier's subsequent oeuvre. And it is to an analysis of some of its most important writings that we must now turn.

\section{ii. The cours d'économie politique}

The years following the publication of the Système de la Méditerranée saw an important number of works that stressed the circulatory system and its generative function. Chevalier's famous 1836 Lettres sur l'Amérique du Nord emphasised the intricacy and density of America’s network of railways, roads, canals, navigable rivers and lakes, and showed how much vaster and more complex it was than that of European nations, including Britain. ${ }^{123}$ This system engendered remarkable economic growth and enormous material abundance, allowing Americans to enjoy high standards of living and a degree of social peace alien to a country like France. ${ }^{124}$ America represented the realisation of what remained an ideal for Europe, and Chevalier said so in his technical and lengthy 1840 Histoire et description des voies de communication aux Etats-Unis et travaux d'art qui en dépendent.

\footnotetext{
${ }^{122}$ Chevalier, Système de la Méditerranée, 148. In later years Chevalier mapped the central arteries of his global system, which included a canals at Suez and Nicaragua and a railway tunnel under the English Channel. See Chevalier, L'isthme de Panama: examen historique et géographique des différentes directions suivant lesquelles on pourrait le percer et des moyens à y employer (Paris: Charles Gosselin, 1844); Chevalier, Tunnel sous-marin entre la France et l'Angleterre sous le Pas-deCalais: description des travaux préliminaires, puits de sondage, carte de sondages, profil en long (Paris: n.p., 1874).

${ }^{123}$ See, for instance, the $7^{\text {th }}$ and $8^{\text {th }}$ letters, Lettres sur l'Amérique du Nord, I, 76-90.

124 'Lettre 9’, Ibid, 97.
} 
Chevalier’s impressive Des intérêts matériels en France (1837) was his attempt to set out a public policy agenda for the French State. It stressed the same message of his earlier works on the need to develop France’s infrastructure. But it also tackled important environmental questions. It was highly critical of the intensive exploitation of the forests of the Pyrénées, Alps, and Vosges, and argued that this practice precipitated flooding, soil erosion and climate change: "With an unregulated deforestation, our temperate provinces become more like southern regions." ${ }^{125}$ Whole populations were put at risk by deforestation. Its effects, whether drought or flash flooding, threatened water supplies, the utility of navigable waterways for transport, industry, and agriculture. The only solution was regulation and the extensive replanting of denuded regions. ${ }^{126}$ Chevalier championed these ideas in administrative and scientific fora, including the Société forestière and the Société d'agriculture of Haute-Vienne. ${ }^{127}$ He was praised for these efforts by leading sylviculturalists, including Henri Vicaire. ${ }^{128}$

Des intérêts matériels en France treated these environmental questions in the round, linking them to local, regional and national agricultural and industrial considerations. Its ideas were buttressed by rigorous theoretical developments in organic chemistry, particularly the idea of the circulus, which was to emerge as an important idea on the use of organic and human waste to improve soil nutrients. There were direct policy implications of this work and of later writings, with their focus on networks, circulation, and growth. And there were important theoretical and conceptual

\footnotetext{
${ }^{125}$ Chevalier, Des intérêts materiels en France, 191.

${ }^{126}$ Ibid, 191-2.

${ }^{127}$ For Chevalier's close association with these societies, see Revue des eaux et forêts, (1863), 157; Société d'agriculture, des sciences et arts de la Haute-Vienne (Limoges: Chapoulaud, 1850), 254.

${ }^{128}$ Henri Vicaire, Rechercher les causes des inondations et les moyens d'en prévenir le retour, in Mémoires d'agriculture, d'économie rurale et domestique (Paris: Bouchard-Huzard, 1857), 271-2.
} 
implications too, not least on the political questions of equality and liberty. The weight of these considerations was an important factor in his appointment to the chair of political economy at the Collège de France in 1840.

In the inaugural lecture to his first course of lectures in 1841 and 1842, Chevalier defined political economy as "the science of material interests [...] concerned with how these interests are formed, how they develop, and how they become organised." ${ }^{129}$ As Walch observed many years ago, the focus on the organisation of material interests was very unusual for liberal political economy of this time. The works of Joseph Garnier and Frédéric Bastiat, which dominated liberal political economy in this period, were resolutely wedded to Say, Comte and Dunoyer’s thinking. Chevalier’s political economy was distinct not only by continuing to be wedded to Saint-Simonian concerns and beliefs, as Walch argued, ${ }^{130}$ but by remaining firmly tethered to the natural scientific world-view he inherited from his student days. His theoretical reflections on political economy of the 1840s illustrate this very well.

Chevalier began his inaugural lecture on political economy by stressing the importance of “industry”. It was, he declared, political economy’s “most beautiful gem”. But his definition of both industry and political economy were far from orthodox. He defined industry as comprising three branches, and he ordered them hierarchically. The first was agriculture then came manufacturing and commerce. He ascribed great importance to agriculture, and in so doing underscored humanity’s connection with nature. "When measured by the number of men she employs, by the value of products she creates, alongside her happy influence on the health of the body

${ }^{129}$ Chevalier, “Discours d'ouverture du cours de l'année 1841-42”, Cours d'économie politique fait au collège de France, I, (M.A. Broët, ed.)(Paris, 1842), 33.

${ }^{130}$ Walch, Michel Chevalier économiste saint-simonien, 261. 
and spirit, agriculture is the first of the arts. [...] Political economy, if she forgot agriculture, would commit the same mistake as an astronomer who omitted the sun from his view of the heavens.” ${ }^{131}$ Within a few short paragraphs, Chevalier put to one side this tripartite description of industry, and employed the term generically. In doing this he advanced a conception of industry that in establishing a direct connection between industry and nature - with nature understood in the dual sense of humanity’s external environment and of its internal species-nature - was substantially different from that form of industry advanced by Say and Dunoyer, and Chevalier's contemporaries Bastiat and Garnier.

There is no exaggeration in saying that through industry man will really become the king of creation, the master of the universe. With industry, instead of being oppressed by matter, man will hold it subjugated to his will (...) this will be a conquest of the human spirit, and, it is to that topic that I wish to turn (...) as it is the intelligence of the greatest number, lost as it is today in worries of attaining the necessities of life, compromised and brutalised by toilsome labours, that will be emancipated and restored to its natural activity. $^{132}$

Chevalier's declarations that “instead of being oppressed” by nature, man would subject her to "his will”, appeared to present an idea of man in conflict with nature. But this was not the case, and it was a far cry from the view presented by Dunoyer in L'industrie et la morale. Rather, it was an argument against a political economy that, in stressing unrestricted competition, pitted industry against nature. Chevalier - echoing Chaptal, Dupin and Dutens’ earlier critique - challenged that political economy by presenting a stark account of unrestricted competition as destructive to nature, industry and social relations. It was competition driven by

\footnotetext{
${ }^{131}$ Cours, I, 3. The importance of agriculture to political economy was recognised by Napoleon III who appointed Chevalier to his 1866 Imperial Commission on agriculture. Annales de la société d'Agriculture, sciences, arts et Belles-Lettres du département d'Indre-et-Loire (Tours: Ladevèze, 1866), 152.

${ }^{132}$ Ibid, 12.
} 
short-termism, and Chevalier had witnessed its effects as a mining engineer: where foundries decimated local forests, or in when coal suppliers clear-cut stands of trees in order to build disposable barges to transport coal to market - barges that, after a single use, were sold for firewood. ${ }^{133}$ It was competition that stifled innovation and investment, and was reflected in cheap but inefficient modes of transportation, which resulted in the waste of valuable resources. He observed first-hand how poor transport led to the deterioration of certain types of coal through prolonged exposure to air, ${ }^{134}$ or how it resulted in the waste of valuable food, such as grain. ${ }^{135}$ The drive to maximise short-term profits led to a lack of investment in new technologies that could improve crop yields, reduce food costs and improve the condition of the working-classes. ${ }^{136}$ Chevalier took an active role in promoting new and significantly more efficient harvesting technologies, such as Cyrus McCormick's wheat reaper, and new applications of organic chemistry, such as the use of fertilizers, especially guano whose effects on improving soil nutrients were well documented, or in experimenting with organic compounds in combatting phylloxera. ${ }^{137}$

Chevalier not only detailed the effects of unfettered competition on the environment, he also observed how it pitted industrialists against each other and against their employees; it caused individuals to be alienated from their labours, and

\footnotetext{
${ }^{133}$ He documented and attacked this practice in Observations sur les Mines de Mons, 455-6.

134 Ibid., 471-2.

135 Chevalier, Les forces alimentaires des états et des devoirs du gouvernement dans la crise actuelle (Paris: au Bureau de la Revue des Deux Mondes, 1847), 14-15.

${ }^{136}$ Chevalier, Les forces alimentaires, 21.

137 On Chevalier's interest in McCormick's wheat reaper see Bulletin des séances de la société royale et centrale d'agriculture 1853-1854, ${ }^{\text {nd }}$ series, vol. 9, (Paris: Mme Huzard, 1853), 198. Chevalier, along with France's leading organic chemists, Dumas and Bossingault, gave strong support to J.A. Barral's Société Générale des Guanos et Pêcheries du Nord. See L'Echo Saumurois, 25 June 1870, 3. He also argued for the removal of the surtax on guano. See Chevalier, Industrie moderne, 39-40, 68. On his important experimental work on combatting phylloxera see Bulletin des séances de la société royale et centrale d'agriculture, 36 (1876), 54.
} 
impoverished the labouring classes morally, intellectually, and culturally. Unfettered competition undermined social peace and cohesion, and led to the disaggregation of social organisation.

Unlimited competition, which is the sole law of industry and which makes masters enemies of one another, obliges them on penalty of bankruptcy, that is to say industrial death, to increase relentlessly and without limit the work of the labourer (...). Competition constrains the worker to look upon his neighbour as a rival who challenges him for his bread. It appears that the genius of war, repelled by the good sense of nations and governments, has sought to save itself in industry. ${ }^{138}$

By depicting unfettered markets in this light, Chevalier presented his audience with a stark choice for the future. The first scenario involved a world in which competition resulted in the destruction of small- and medium-size producers and a concentration of capital in the hands of a few producers. The result was a new “industrial feudalism” in which a dangerous opposition between humanity and nature would express itself at the micro-level in the alienated individual "compromised and brutalised by toilsome labours” and at the macro-level in the fragmented society and divided international order. The second scenario encompassed the idea of organisation and an intimate association of competing interests brought together through a complex infrastructure and banking system. Within this scenario he offered a different conception of competition and trade from liberal political economists. Unlike Dunoyer, Garnier or Bastiat who adhered to the language of politics and understood competition and free trade as the expression of individual liberty, the absence of constraint on the individual's will, Chevalier viewed them very differently, seeing them as integral to a wider idea of organisation based on a sophisticated understanding of the laws of nature and the generative capacity of natural systems. Trade was a form of circulus that acted as a catalyst to innovation and the elimination

${ }^{138}$ Cours, I, 17-18. 
of damaging environmental practices. ${ }^{139}$ And he contrasted trade within the

organisation of a system rooted in a deep understanding of nature with the disorder of unrestricted competition.

[...] unlimited competition often causes an excessive fall in prices that appears favourable to the consumer. What occurs after all of these accidents, these extreme depressions, these jolts and these shocks, is not only a transfer of wealth to some and a loss to others; it is rather in the greater number of cases a dead loss. For the theorem of kinetic energies that mathematicians establish in relation to the movement of solid objects, equally subsists in the order of material interests, and perhaps too in the ethical realm. In political economy, just as in rational mechanics (la mécanique rationnnelle), it is true to say that variations subsist and that shocks result in an enormous loss of energy (une énorme déperdition de force). ${ }^{140}$

This account of political economy stressed natural scientific principles, which pertained to energy and movement. And its origins lay in both geology and organic chemistry. This was an account of political economy that was strongly endorsed by natural scientists, agronomists, and sylviculturalists, seeing its value to agriculture, sylviculture, and to public administration. ${ }^{141}$ Journals such as the Annales forestière placed Chevalier's name alongside those major figures who contributed to public service in France, and in particular the administration of its forests: an administration based on, in its words, the "natural and economic sciences". ${ }^{142}$ This was a vision of political economy very much at odds with the defence of unfettered markets found in the liberal political economy of Dunoyer, Garnier and Bastiat.

\footnotetext{
${ }^{139}$ Chevalier stressed these benefits in speeches to the Conseil Général de l'Hérault of which he was president. See Procès verbaux du Conseil Général de l'Hérault 26 August 1861, and 25 August 1862. Archives départementales de l'Hérault, 1 N 35 \& 1 N 36.

${ }^{140}$ Cours, I, 22.

${ }^{141}$ The Annales forestière highlighted the importance of Chevalier's lectures to agriculture and

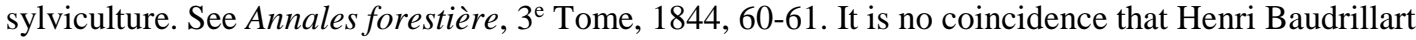
(1821-1892), one of France's leading sylviculturalists, would serve as Chevalier's assistant lecturer in political economy at the Collège de France. Chevalier himself played a prominent role in the Société d'Agriculture de la Haute Vienne.

${ }^{142}$ Annales forestière, $15^{\mathrm{e}}$ Tome, 1856, 2.
} 
Chevalier's political economy was defined by organisation and circulatory systems, and these were central to his reflections on commerce and global trade. These systems were organised. They consolidated diverse elements, gave shape and direction to what would otherwise be chaotic and conflictual activity. Though Chevalier collaborated with both Bastiat and Garnier in writing for the Journal des économistes and in participating in L'Association pour la liberté des échanges, his participation was, as David Todd observed, "lukewarm”. ${ }^{143}$ This was because his reflections on commerce were underpinned by a set of wholly different assumptions. He viewed commerce in terms of its ability to bring together disparate elements, to forge common interests, or, as he said, to "create everywhere mutual interests”, to achieve "universal association”. ${ }^{144}$ These interests combined to generate growth and new interests, and these in turn combined to generate additional growth and interests. The circulatory system multiplied interests, connections, and development.

The connection Chevalier established between the circulatory system and its generative capacity was thoroughly explored in his lectures when he examined all forms of infrastructure networks, from the physical networks of roads, canals, and railways, to the networks of financial capital that stimulated investment. ${ }^{145}$ To these were added the knowledge networks - domestic and international - of science and technology, the very stuff of the societies of Arcueil and philomathique. ${ }^{146}$ All of these networks fuelled the growth of "productive forces" and the associative connections between individuals, classes, and nations. They were integral to the

\footnotetext{
${ }^{143}$ Todd, “Transnational Projects”, 17.

${ }^{144}$ Chevalier, Cours, 1841-42, 27.

${ }^{145}$ Chevalier's account of capital circulation made up his theory of credit. This was the topic of his ninth lecture.

${ }^{146}$ These topics were the object of the $4^{\text {th }} 5^{\text {th }}$ and $6^{\text {th }}$ of $1842-43$, Cours, 125-197.
} 
"spirit of association" and "human fraternity", and central to his history of the development of civilisation. ${ }^{147}$

Just how important networks and the idea of generative capacity were to Chevalier's economic thought was made crystal clear when he confronted the question of how economic crises came about. He defied the economic orthodoxy of his day, which was itself divided on the nature of crises. Those following Say rejected Simonde de Sismondi's argument from his 1819 Nouveaux principes d'économie politique that economic crises resulted from overproduction. Instead they contended that supply created its own demand and that equilibrium would always be achieved. Chevalier navigated a different course. Like Sismondi he believed crises resulted largely from overproduction or underconsumption, and he argued for increasing aggregate demand through increasing average wages. ${ }^{148}$ But this solution was inadequate on its own and additional measures were necessary, which involved the development of infrastructure networks, better access to financial capital and sources of credit, the promotion of trade, the scientific development and management of natural and human resources. Solving the problem of achieving a better economic equilibrium was the focus of much of his 1842-43 lectures, which argued for an expansive role for the state, especially its direct involvement in public works and infrastructure development. ${ }^{149}$ Chevalier, in returning to the tropes of industrie and Saint-Simonianism, contrasted the new industrial state with the warrior state of the Old Regime. The latter "brought about the destruction of men and wealth" the former

\footnotetext{
${ }^{147}$ Ibid, 100.

${ }^{148}$ Letters 9 and 13 describe wages and living conditions in the United States, 97-8, 134-9.

${ }^{149}$ Cours, 1842-43, 11.
} 
"spurred their creation.” 150 Ten lectures from this period were devoted to the new industrial state and how it could direct the activities of its military away from warfare and toward public works. These lectures rejoined the first of his politique industrielle articles from his time as editor of the Globe just as they anticipated his important 1848 L'Organisation du travail, ${ }^{151}$ and the work he would undertake as a member of Napoleon III’s Council of State in developing France’s infrastructure. ${ }^{152}$ The underlying assumption of these lectures was contained in his remark about rational mechanics cited earlier. The scientific world-view on the interconnectedness of all phenomena that Chevalier retained from his time at the École polytechnique and the École des mines, crystallised in his view of the state. The modern, scientific state, organised the "veins and arteries" of the nation. Through its complex network of canals, rivers, roads, telegraphs, and railways, the state developed its natural and human resources and thereby grew the nation's generative capacity. The state was the nation's underlying unifying principle. It bore a striking family resemblance to Bertholet's unifying principle of all organic phenomena or Saint-Simon's principal of universal gravitation. And it was a conception of the state that differed radically from that enunciated by Bastiat, Dunoyer, or Garnier who saw it as interfering and disruptive to economic and social equilibrium.

\section{Conclusion}

In ascribing a central role to the state in the development of infrastructure and communication networks, Chevalier highlighted two contrasting orders and, by

\footnotetext{
${ }^{150}$ Ibid, 15.

${ }^{151}$ Walch, Michel Chevalier économiste saint-simonien, 444.

${ }^{152}$ Drolet, “Industry, Class and Society”, 1261.
} 
implication, two contrasting visions of political economy. The first order dominated by unfettered markets and competition, and championed by Dunoyer, Garnier and Bastiat, was characterised by conflict and the waste of human and natural resources. The second order - the new age of industrie - was characterised by an intricate web of networks whose complexity and diversity determined its generative capacity. The more complex and diverse the web the more growth it created. At the heart of this idea was a sophisticated understanding of nature as a circulatory system and complex web of life. What permitted this idea to be mapped onto society was the belief that nature and society were symbiotically united in this system. The consequences of this were immense for Chevalier's political economic thought. Yet those consequences have never been fully appreciated because his thought has only ever been interpreted through established categories of political and economic theory, and this has left us with an impoverished understanding of nineteenth-century French political economy more generally. Only by being sensitive to the natural scientific background to nineteenth-century French political economy can its richness and relevance to our own economic and ecological predicament be fully appreciated.

Acknowledgments: I wish to express my thanks to the following institutions that assisted me in writing this article. I am grateful to the British Academy (grant no.SG101903), the Faculty of History, University of Oxford, and Stanford University Library for their generous funding. A number of archives opened their collections to me, and I am grateful to the École Nationale Supérieure des Mines de Paris, the Académie Royale de Beligique, the Archives départementales de l'Hérault, the Archives départementales de la Haute Vienne, Archives Nationales de France, Georgetown University Library Special Collections Research Center, The Parks Library, Iowa State University. I am grateful to Ulrich Pässler of the Berlin-Brandenburgische Akademie der Wissenschaften, Eric Willey of the McCormickInternational Harvester Collection Library-Archives Division Wisconsin Historical Society, and Sarah Sussman, Stanford University Library, who facilitated my access to the Gustave Gimon Collection, and was the most hospitable of hosts during my stay at Stanford. A very special thanks to Olivier Azola, archivist at the École Polytechnique de Paris, who was incredibly generous with his time and helped me uncover some fascinating material. The following individuals offered generously of their time and advice: Pietro Corsi, Ludovic Frobert, Sudhir Hazareesingh, Joanna Innes, Jeremy Jennings, Alan Kahan, Eduardo Pasado-Carbo, Mark Philp, Philippe Régnier, Lyndal Roper, Nicholas Stargardt, and Andrea Wulf. I am most grateful to you all. I wish to record my thanks to the anonymous readers who took time and care in reading an earlier draft of this article. Their shrewd observations and constructive criticisms were greatly appreciated. And finally, I wish to thank Sophie Rosenfeld and the editors of Modern Intellectual History for their sage editorial advice. 